THE TYNDALE BIBLICAL THEOLOGY LECTURE, 1981

\title{
COVENANT: THE KEY TO PAUL'S CONFLICT WITH CORINTH
}

By William L. Lane

One line of biblical research has explored the concept of the prophet as servant of the covenant and messenger of Yahweh. Attention has been focused upon passages which represent Yahweh and his people as adversaries in a legal process.! The basis for the controversy is the covenant relationship between God and Israel, which has been ruptured by the callous indifference of the people. The prophet has stood in the council of Yahweh and has heard his complaint (cf. Je. 23:16-22). The violation of the stipulations of the covenant merits the threat of imposing the curse sanctions which are integral to the covenant. The prophet is commissioned to express Yahweh's complaint to his faithless vassal.

In this context the prophetic word assumes the form of the $R \hat{i} b$ or lawsuit. ${ }^{2}$ The modes of speech employed

1. E.g. Is. $1: 2-3,18-20$; 3:13-15; Mi. $6: 1-5$; Ho. 2:4-17; $4: 1-3,4-6 ; 12: 3-15$; Je. $2: 2-37 ; 25: 31$; Mal. $3: 5$.

2. Cf. E. Würthwein, 'Der Ursprung der prophetischen Gerichtsrede', ZTK 49 (1952) 1-16; B. Gemser, 'The $R \hat{I} B-$ or Controversy-Pattern in Hebrew Mentality', in Wisdom in Israel and in the Ancient Near East, ed. M. Noth and D. W. Thomas (VT Supplements, 3, 1955) 120137; H. B. Huffmon, 'The Covenant Lawsuit in the Prophets', JBL 78 (1959) 285-295; G. E. Wright, 'The Lawsuit of God: A Form-Critical Study of Deuteronomy 32', in Israel's Prophetic Heritage, ed. B. W.

Anderson and $W$. Harrelson (New York, 1962) 26-67; J. Harvey, 'Le "Rîb-Pattern", réquisitoire prophêtique sur la rupture de l'alliance', Bib 43 (1962) 172196; E. von Waldon, Die traditionsgeschichtliche Hintergrund der prophetischen Gerichtreden (Berlin, 1963); E. C. Kingsbury, 'The Prophets and the Council of Yahweh', JBL 83 (1964) 279-286; J. Harvey, Le Plaidoyer prophétique contre Israël après la rupture de I'alliance (Paris, 1969); J. Limburg, 'The Lawsuit 
originated in the sphere of international relationships in the ancient Near.East. ${ }^{3}$ Whenever a vassal failed to comply with the stipulations of the treaty with his suzerain, he could anticipate the arrival of a royal messenger bearing a formal complaint for breach of sacral law. J. Limburg comments: 'The figure of the royal messenger, bringing a complaint against a people, provides a kind of model for understanding the figure of

of God in the Eighth Century Prophets' (Dissertation, Union Theological Seminary (VA) 1969); idem, 'The Root ריב and the Prophet Lawsuit Speeches', JBL 88 (1969) 291-304; K. Nielsen, Yahweh as Prosecutor and Judge. An Investigation of the Prophetic Lawsuit (Rîb-Pattern) (Sheffield, 1978).

3. Cf. G. Mendenhall, Law and Covenant in Israel and the Ancient Near East (Pittsburgh, 1955); K. Baltzer, Das Bundesformular (Neukirchen, 1960, rev. 1964; E. T., The Covenant Formulary in Old Testament, Jewish, and Early Christian Writings, Philadelphia, 1971); M. Kline, Treaty of the Great King (Grand Rapids, 1963) 13-44; D. J. McCarthy, Treaty and Covenant: A Study in Form in the Ancient Oriental Documents and in the old Testament (Rome, 1963); idem, Das Gottesbund im Alten Testament (Stuttgart, 1966, rev. 1967); J. A. Thompson, The Ancient Near Eastern Treaties and the old Testament (Grand Rapids, 1964); J. Limburg, 'Lawsuit' 297-304. For a dissenting point of view see especially F. Nötscher, 'Bundesformular und "Amtsschimmel"', BZ NS 9 (1965) 181-214; G. Fohrer, 'Altes Testament - "Amphiktyonie" und "Bund"?' Th.L. 91 (1966) cols. 801-816, 893-904; E. Kutsch, 'Gesetz und Gnade', ZAW 79 (1967) 18-35; idem, ' 'b Handwörterbuch zum Alten Testament I (1971) 339-552. These writers affirm that the traditional translation of berith as 'covenant' has been proven to be erroneous, and that the word actually means 'obligation': the obligation a person undertakes for himself, the obligation a person can impose upon another, and mutual obligation. The note of obligation is certainly integral to the suzerain-vassal relationship. Consequently, even if those dissenting scholars prove to be correct in their understanding of berith, the fundamental character of the breach of berith and the lawsuit which ensues remains unchanged. 
the prophet, announcing that Yahweh has a complaint against his people'. ${ }^{4}$ The prophet functions as the messenger of the covenant lawsuit of God. 5

In the ancient Near East the lawsuit between a suzerain and his vassal progressed in two stages. In the initial stage one or several preliminary warnings were conveyed by letter delivered by a royal messenger. The suzerain demanded an explanation for the irregularities in his vassal's behaviour. The point by point review of the clauses of the treaty and of the benefactions that led to its establishment was intended to reinforce the demand for repentance and compliance, under threat of the imposing of the curse sanctions of the treaty. A significant response was expected from the vassal. If the diplomatic messenger was detained in prison, abused, or slain, the lawsuit advanced to a second stage, with a declaration of war and the actualization of the curse. sanctions of the treaty. 6

In their role as messengers of the Great King the prophets delivered to Israel repeated warnings that breach of allegiance to God would be punished by the withdrawal of the divine favour and the imposing of the curse sanctions of the covenant. Israel's experience of defeat, humiliation, and exile was the consequence of disregarding the ultimatum. Sustained contempt for God was the occasion for the execution of the sentence of destruction.

4. J. Limburg, 'Lawsuit', 304, n. 41.

5. On the role of the messenger in the ancient Orient see J. M. Munn-Rankin, 'Diplomacy in Western Asia in the Early Second Millennium B.C.', Iraq 18 (1956) 102ff and C. Westermann, Grundformen prophetischer Rede (BEvT 31, 1960) 70-91.

6. On war as a legal process see V. Korołec, 'The Warfare of the Hittites - From the Legal Point of View', Iraq 25 (1963) 164; D. J. McCarthy, Treaty 92f. The establishment of the international treaties under the sanctions of the gods had the corollary that military engagement occasioned by the violation of a treaty was a trial by ordeal, a judgment by the deities invoked at the time the oath of allegiance was sworn by the vassal. 
The dynamics of the administration of the covenant illumine the distinctive character of the ministry of the prophets as servants of the covenant. But reflection upon the covenant and its administration is not limited to the documents of the old Testament. Klaus Baltzer has traced the basic structure of the covenant formulary in certain Jewish and early Christian. documents as well. ${ }^{7}$ He has marshalled substantial evidence that in the communities responsible for these later documents it was normal to think in the categories of covenant status and obligation. The promise of the New Covenant in Jeremiah 31 accounted for this development. This text provided a point of crystallization for the self-consciousness both of the Essene movement and of the early Christian community. Baltzer's investigation suggests that a pastoral response to a disruptive situation in the first century of the Christian era would entail an appeal to the New Covenant and the administration of its provisions.

This proposal may be tested by reference to Paul's pastoral response to the disruptive situation at Corinth. Three considerations encourage this biblicaltheological investigation.

(1) When Paul refers to his own experience of the call of God he writes of consecration to a task prior to birth and of appointment to preach to the Gentiles:

He who had set me apart before I was born, and had called me through his grace, was pleased to reveal his Son to me, in order that I might preach him among the Gentiles... (Gal. 1:15f).

This mode of expression is reminiscent of the call to the prophetic office addressed to Jeremiah; to whom God said:

7. K. Baltzer, Covenant Formulary 97-180 traced the covenant formulary in documents from Qumran (1QS, CD), Jubilees, Testaments of the Twelve Patriarchs, the Epistle of Barnabas, the Didache, and 2 Clement. J. Reumann, 'Heilsgeschichte in Luke', in Studia Evangelica IV, ed. F. L. Cross (Berlin, 1968) 108115, applies Baltzer's thesis to the New Testament.

8. K. Baltzer, Covenant Formulary 167-178. 
Before I formed you in the womb I knew you, and before you were born I consecrated you; I appointed you a prophet to the Gentiles (Je. 1:5).

The two factors of consecration to the service of God prior to birth and of appointment to the Gentiles characterize the servant of the Lord in Isaiah 49:1-6 as well.

Listen to me, o coastlands, and hearken, you peoples from afar. The Lord called me from the womb, from the body of my mother he named my name. ... and he said to me, 'You are my servant ... in whom I will be glorified'.

And now the Lord says, who formed me from the womb to be his servant, to bring Jacob back to him, and that Israel might be gathered to him, ...

'It is too light a thing that you should be my servant to raise up the tribes of Jacob and to restore the remnant of Israel;

I will give you as a light to the Gentiles that my salvation may reach to the ends of the earth'. (Is. 49:1,3,5-6)

Paul's formulation of his vocation in Galatians 1:15f is evidence of his reflection on the call and commission of Jeremiah and of the Isaianic servant of the Lord. It indicates that he has been called to the prophetic vocation. ${ }^{9}$

(2) Paul defines the character of his ministry by referring to the New Covenant of Jeremiah $31: 27-34 .^{10}$

9. Cf. A. M. Denis, 'L'Apôtre Paul, prophète "messianique" des Gentiles. Étude thématique de I Thess. II, 1-6', ETL 33 (1957) 245-318; J. Munck, Paul and the Salvation of Mankind (Richmond, 1959) 11-35, esp. 26-29; K. Stendahl, Paul Among Jews and Gentiles (Philadelphia, 1976) 8-10.

10. On this important passage see H. Ortmann, Der alte und der neue Bund bei Jeremia (Dissertation, Berlin, 1940); W. Lempp, Bund und Bundeserneuerung bei Jeremia (Di.ssertation, Tübingen, 1955); R. Schreiber, Der neue Bund in Spätjudentum und Christentum (Dissertation, Tübingen, 1955); R. 
The ratification of the New Coyenant through Jesus' death (cf. 1 Cor. 11:25) implied the beginning of a new history for the people of God. It created the theological context for the appointment of new prophets committed to the administration of the covenant. In 2 Corinthians 3:1-18 Paul grounds his ministry in the appointment of God who qualified him to be a 'servant of the New Covenant' $(3: 6)$, in distinction from the Mosaic service of the covenant established at Sinai $(3: 6-14)$. The analogy with Moses that Paul develops, and the assertion of the superiority of his ministry because of its eschatological glory, justify the conclusion that Paul regarded himself as the Second Moses to the New Covenant community. ${ }^{1}$ As Moses was preeminently the mediator and prophet of the old Covenant, Paul is the mediator and prophet of the New Covenant. His pastoral ministry is an expression of covenant administration.

It is equally important to recognize the scope of the covenantal role of the Isaianic servant. He is the full counterpart of Moses, the servant of Yahweh and mediator of the covenant. The primary force of Isaiah 49:1-13 is that the servant bxings the salvation of the redemptive covenant. His ministry marks the renewal of the covenant with Israel and the extension of redemption to the nations of the world. Although the servant is treated with contempt and judges his mission to be a failure (Is. 49:4,7), he will be vindicated and God's purpose will be realized (Is. 49:7-13).

A case can be made for affirming that Paul found in Isaiah 49:1-13 a pattern for expressing his call to

Martin-Achard, 'La nouvelle alliance selon Jérémie', RThPh 1.2 (1962) 81-92; J. Coppens, 'La Nouvelle Alliance en Jér. 31:31-34', CBQ 25 (1963) 12-21; S. Herrmann, Die prophetische Heilserwartungen im Alten Testament (Stuttgart, 1965) 179ff; J. Bright, 'An Exercise in Hermeneutics, Jeremiah 31:31-34', Int 20 (1966) 188-210; w. L. Holladay, 'The New Covenant', IDB Supp. Vol. (1976) 623-625.

11. See P. Jones, 'The Apostle Paul: Second Moses to the New Covenant Community. A study in Pauline Apostolic Authority', in God's Inerrant Word, ed. J. W. Montgomery (Minneapolis, 1974) 220-234. 
mission and a paradigm for understanding his experience among the Gentiles. He cites Isaiah 49:8 in 2 Corinthians $6: 2$ at a time when he is responding to disparagement and finds in that Isaianic text the assurance that he will be vindicated. The trajectory between Paul and Moses can be traced through the Isaianic servant and supports a covenantal interpretation of Paul's ministry. 12

(3) In writing to the Corinthians Paul describes his commission in terms of 'building up' and 'tearing down' (2 Cor. 10:8; 13:10; cf. Gal. 2:18). This distinctive imagery indicates that Paul turned to Jeremiah for an understanding of the covenantal tasks for which he had been chosen by God. To the reluctant son of Hilkiah God had addressed the word of instruction,

See, I have appointed you this day over the Gentiles and over kingdoms, to pluck up and to tear down, to destroy and to overthrow, to build up and to plant. (Je. $1: 10$ )

These terms descriptive of the ministry entrusted to Jeremiah are reiterated throughout the book to define the activity of God among his people and among the Gentiles (Je. 12:14-17; 18:7-11; 24:6f; 31:27-28; 42:10; 45:4). They recur in the preamble to the promise to establish the New Covenant:

And it shall come to pass that as I have watched over them to pluck up and to tear down, to overthrow, destroy, and bring evil, so I will watch over them to build and to plant, says the Lord (Je. 31:28).

In describing the New Covenant ministry entrusted to him, Paul speaks of his authority for building, and not for tearing down (2 Cor. 13:10). The explicit allusion

12. Ibid. 228-230. Cf. L. Cerfaux, 'St. Paul et le "serviteur de Dieu" d'Isaïe', Recueil L. Cerfaux, II (Gembloux, 1954) 439-454; D. M. Stanley, 'The Theme of the Servant of Jahweh in Primitive Christian Soteriology and its Transposition by St. Paul', CBQ 16 (1964) 385-425; A. Bertrangs, 'La vocation des Gentiles chez St. Paul: Exêgèse et hermeneutique pauliniennes des citations veterotestamentaire", ETL 30 (1954) 391-415; J. Giblet, 'St. Paul, serviteur de Dieu et apôtre de Jésus Christ', Vie Spirituelle 388 (1953) 244-265. 
to Jeremiah 31:28 indicates that Paul understood his task as the eschatological ministry of establishing the New Covenant, an act of God prophesied through Jeremiah and achieved through Paul as the servant of the covenant. ${ }^{13}$

Paul's appointment to his office reaffirmed God's gracious disposition toward the Gentiles expressed through Isaiah and Jeremiah. God had summoned him to assume responsibility for the prophetic task of addressing the Gentiles with the message of salvation, carrying forward the mission entrusted to the servant of the Lord. The covenantal character of his ministry provided the assurance that God's grace would indeed be extended to the Gentiles through the ministry of his servant. The disruptions at Corinth, however, displayed a callous insensitivity to the New Covenant. Paul was mandated by God to express the divine complaint against the rebellious Corinthians and to call them back to the stipulations of the covenant. In this instance, Paul functioned as the messenger of the covenant lawsuit of God. I have become convinced that this insight provides a necessary key for appreciating the character, content, and unity of 2 Corinthians. A review of Paul's relationship to the Corinthians will serve to establish a context for developing this thesis.

The reconstruction of Paul's relationship to the Corinthians remains problematical. The sole basis for charting what took place after the writing of 1 Corinthians is 2 Corinthians. That letter frequently frustrates us with its failure to provide the specific information which could clarify the chequered early history of Christianity on the Isthmus. The details were so well known to Paul and to the Corinthians that allusions were sufficient to recall the course of events. In seeking to understand what occurred the historian is at many points reduced to inference and conjecture.

The founding visit can be assigned to the eighteenmonth period extending from the autumn of A.D. 50 to the spring of 52 (Acts 18:1-18). When Paul took up

13. P. Jones, 'Apostle Paul' 221. 
residence in Ephesus on his third missionary journey he was able to resume his contacts with the Corinthians. He heard disturbing news concerning the level of morality within the congregation, and addressed this issue in a brief letter which has not been preserved (cf. 1 Cor. 5:9-11). The Corinthians responded with their own letter (cf. 1 Cor. 7:1), which was delivered by Stephanas, Fortunatus and Achaicus (1 Cor. 16:15-18). Paul was kept informed concerning the unstable situation at Corinth by members of Chloe's household (1 Cor. 1:10-12; 5:1f; 11:18). He responded to the immaturity, immorality, and confusion in corinth with 1 Corinthians, which was delivered by the threeman deputation upon their return to the Isthmus in the spring of A.D. 55 (1 Cor. 16:5-8,12,17).

Paul recognized that if order was to be restored in the Corinthian congregation pastoral direction was required. He determined to send Timothy overland through Macedonia to represent him in Corinth (1 Cor. 4:16f; cf. Acts 19:2lf). Although Timothy was well known to the Corinthians (2 Cor. 1:19; cf. 1 Thess. 3:6; Acts 18:5), it is evident that Paul was anxious about the reception his delegate would receive.

When Timothy comes, see that you put him at ease among you, for he is doing the work of the Lord, as I am. So let no one despise him. Speed him on his way in peace, that he may return to me, for $I$ am expecting him with the brothers (1 Cor. 16:10f).

Timothy's mission is firmly linked to Paul's own apostolic labours to assure him of a favourable reception. The commands to put him at ease and to permit no one to display contempt for him sufficiently indicate the Apostle's level of concern for Timothy's welfare.

Twice in 2 Corinthians Paul states that he is ready to come to Corinth a third time (12:14; 13:1), while much of the letter is intelligible only in terms of a second visit he has already made to the city (cf. 2:1; 13:3). Unrelieved anxiety over the disorders at Corinth appears to have motivated Paul's own sudden decision to return to Corinth. Acts is silent about this second visit to the city; we know of it only through Paul's own statement (2 Cor. 13:2). It is a plausible conjecture that Paul's visit occurred prior to 
Timothy's arrival, but subsequent to the reception of 1 Corinthians. ${ }^{14}$ All that can be said with certainty, however, is that the visit was brief in duration and painful in character. In retrospect Paul wrote, 'I made up my mind not to make you another painful visit'(2 Cor. $2: 1)$.

Paul's most explicit reference to this second visit occurs near the close of 2 Corinthians where he provides a catalogue of the vices he observed within the church: 'quarrelling, jealousy, anger, selfishness, slander, gossip, conceit and disorder' $(12: 20)$. He expressed a concern that he 'may have to mourn over many of those who sinned before and have not repented of the impurity, immorality, and licentiousness which they practise' (12:21). Anticipating a projected third visit to the city, Paul wrote:

This is the third time I am coming to you... I warned those who sinned before and all the others, and I warn them now while absent, as I did when present on my second visit, that if I come again I will not spare them - since you desire proof that Christ is speaking in me... (13:1-3).

The warning that the practices condemned will be tolerated no longer is tied to the stern warning delivered on the occasion of the second visit.

The practices which Paul observed during his second, unexpected visit to the Isthmus, and which he feared he would find when he came a third time, mirror the congregation addressed in 1 Corinthians. Paul's protest indicates that the pastoral directives in the

14. A sound reason for holding that the reception of 1 Corinthians preceded the arrival of Timothy is that the apostolic instructions in 1 Cor. 16:10f, near the close of the letter, are intended to prepare for Timothy's coming. If Timothy was himself the bearer of 1 Corinthians, it is unlikely the Apostle would have waited until the closing paragraphs of the letter to provide for the respectful reception necessary for the success of his lieutenant's mission. A more likely place for these instructions would have been following 1 Cor. 4:14-17, where Paul first mentions his sending of Timothy. 
earlier letter had not been heeded. Many individuals remained in flagrant sin.

After Paul had administered his strong rebuke to the entire congregation, he withdrew from Corinth, providing the church an opportunity to restore a measure of order to its corporate life. The painfulness of the visit for Paul (cf. 2 Cor. 2:1, 'another painful visit') lay in the severity with which it had been necessary to castigate the Corinthians for their moral disarray and disregard for church order. He shrank from the prospect that he would have to exercise his prophetic authority in 'tearing down' rather than 'building up' a church he had established and nurtured (2 Cor. 13:9-11). Paul's reluctance to exercise his prophetic authority, however, had encouraged certain arrogant persons in the congregation to disregard the apostolic warning. The sentiment began to gain currency at Corinth that the Apostle's 'letters are weighty and strong, but his bodily presence is weak, and his speech of no account' (2 cor. 10:10; cf. 10:1).

Although Timothy's name is linked with Paul's in the salutation of 2 Corinthians ( $1: 1)$, the letter is strangely silent about his reception in Corinth. Paul's silence on this matter is unexpected. In earlier correspondence he had made a point of commenting on the mission and report of Timothy ( 1 Thess. 3: 1-6), and in 2 Corinthians itself he makes explicit reference to the mission and report of Titus (2 Cor. 2:3-13; 7:5-16). Moreover, Paul's silence would appear to be in conflict with the concern for the success of Timothy's mission he expressed in 1 Corinthians (16: 10f). An explanation can be offered, however, for Paul's failure to comment explicitly in 2 Corinthians on Timothy's reception by the congregation.

The arrival of Timothy as Paul's surrogate could have done little to relieve the severely strained relationship between Paul and the Corinthians. Those who had dismissed Paul as weak and ineffectual would have been incensed by Timothy's presence. It is this volatile situation that has convinced me that the oblique reference to one who suffered injury in Corinth (2 Cor. 
$7: 12)$ is, in fact, an allusion to the reception of
Timothy.

When Timothy arrived in Corinth he was abused. His treatment displayed contempt for Paul. The seriousness of this development is evident when the official character of Timothy's representative status is recognized. Paul had clearly stated that he was sending Timothy to Corinth as his delegate (1 Cor. 4:16f). By virtue of his commission Timothy was himself a messenger of the covenant, charged to review point by point the ethical stipulations of the covenant that were being flagrantly violated by the Corinthians. The abuse of Timothy, and the contempt for his mission which it displayed, exposed the Corinthians to dire jeopardy. When Paul wrote 2 Corinthians reconciliation had been achieved. To have reviewed the course of events surrounding Timothy's arrival would only have occasioned renewed pain. Paul's oblique reference was sufficient to place the issue delicately, but clearly, before his readers.

When Timothy returned and reported what he had experienced, Paul wrote to Corinth a letter so severe that it grieved him later even to think of what he had written (2 Cor. 2:2-11; 7:8-13). The letter is now lost, but the circumstances surrounding its composition and the response to its demands are prominently in view in 2 Corinthians 2 and 7 . The severe letter posed an ultimatum to punish the one who had inflicted the injury

15. It is also possible that Timothy is the brother referred to in 2 Cor. 8:22 ('we are sending our brother whom. we have often tested and found earnest in many matters, but who is now more earnest than ever because of his great confidence in you') since in 2 Cor. 1:1 he is introduced as 'Timothy our brother'. For a summary of research on the question see P. Hughes, Paul's Second Epistle to the Corinthians (Grand Rapids, 1962) 312-316. Cf. G. W. H. Lampe, 'Church Discipline and the Interpretation of the Epistles to the Corinthians', in Christian History and Interpretation, ed. W. R. Farmer et al. (Cambridge, 1967) 353: '[the reference in II Cor. 7:12] suits a situation in which Paul or one of his associates (possibly Timothy) has been insulted by someone at Corinth...'. 
and to demonstrate an acceptable repentance or to experience the curse sanctions of the covenant (cf. 1 Cor. $11: 20-22,27-30) .16$

The bearer of this 'painful letter' was Titus, whom Paul dispatched to Corinth with the instruction to report to him at Troas as soon as the response of the congregation was known. When Paul arrived in Troas and failed to find his associate, he became so disquieted he could not remain in the city (2 Cor. 2:12f). He hastened to Macedonia where he finally met Titus en route with the news that the Corinthians had responded to the letter with godly sorrow. In accordance with the judgment of the majority $(7: 5-7)$ they had punished the offending member who had abused Paul's emissary. That report was the immediate occasion of 2 Corinthians, a letter which reflects the alternating depths of anguish and affection, grief and joy, affliction and comfort which paul had experienced in the severely strained situation at Corinth.

\section{III}

In the course of responding to the Corinthians Paul appeals to the New Covenant and the ministry entrusted to him by God. The significance of this is evident once the pattern of unacceptable behaviour, unheeded instruction (1 Corinthians), visitation and warning (Paul's second visit), abuse of an emissary (Timothy), followed by a letter of ultimatum demanding repentance and restoration (the painful letter), is recognized. The sequence corresponds to the course of the covenant lawsuit of God expressed through the prophets. Although the structure of 2 Corinthians does not conform to the

16. For the alternative proposal that the painful letter is 1 Corinthians, see A. M. G. Stephenson, 'A Defence of the Integrity of 2 Corinthians', in $K$. Aland et al., The Authorship and Integrity of the New Testament (London, 1965) 85-97; P. Hughes, Second Corinthians xxviii-xxx, 54-65, 275-278. The chief objection to this proposal is the description of the depth of repentance the letter produced within the congregation, and the personal significance which Paul attached to its provisions (e.g. 2 Cor. $7: 13$, 'that your zeal for us might be revealed to you in the sight of God'). In point of fact, 2 Corinthians (12:20f) indicates that the matters 
formal $\cdot \hat{i} b$ pattern, a $R \hat{i} b$ ideology offers a cogent explanation of both the structure and content of the letter and sheds considerable light on specific details of Paul's response.

The theological core of Second Corinthians extends from $3: 1-7: 1$, and finds its coherence in the concept of the New Covenant concluded between God and his people. Both the content and structure of Paul's thought are intelligible from the perspective of covenant lawsuit ideology. Paul's purpose is to call the Corinthians to renew their commitment to the Lord and to complete the obedience they have already begun to manifest in response to his 'letter of tears'. By stressing the eschatological superiority of the new ministry with which he has been entrusted by God to the older ministry committed to Moses, Paul was able to throw into bold relief the urgency of his pastoral appeal.

Throughout chapter 3 Paul contrasts the surpassing splendour of the New Covenant with the faded glory that once attended the old Covenant. The Apostle's argument is distinctly covenantal in character. Not only is reference made to the Scriptures of 'the old covenant' (3:14), but explicit appeal is made to 'the new covenant' $(3: 6)$. In contrast to tables of stone and a written code which possessed no ability to effect the heavy demands it imposed, which constituted the symbols of the older ministry, the human heart bearing the signature of Christ and empowered by the spirit of God is the symbol of the new $(3: 1-3)$.

In the development of the argument, Paul defines his

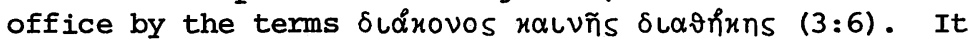
is important to appreciate how the corinthians would have understood the nuances intended in this selfdesignation. In classical and hellenistic Greek


of hellenistic texts attest a distinctly religious connotation to the term.18 In writers contemporary with

which Paul treated in 1 Corinthians remained unresolved in Corinth.

17. ISJ 398 cite Aeschylus, Prom. 942; Sophocles, Phil. 497 and Fragment 133.

18. $M M 149$ cite inscriptional evidence from Magnesia and elsewhere: Inscript. Magn. 109, 217; IG 9.1, 486; 4.774.11; CIG 2.1800, 3037 . 
Paul the term conveys the idea of representation as well as service. Epictetus, for example, speaks of the wise man as a 'servant of God', who functions as both the instrument and witness of God. ${ }^{19}$ Julius Pollux, a grammarian of the second century A,D., lists $\delta$ láxovos as an equivalent for 'ambassador'. The Corinthians would have understood Paul to be saying that he was 'the messenger' of God. Paul's repeated affirmation that he had been commissioned by God to speak the word entrusted to him (cf. 2 Cor. 1:21; 2:17; 4:2; 5:18-20; 6:7) actually pointed in that direction.


the papyri and inscriptions of the hellenistic period, 20

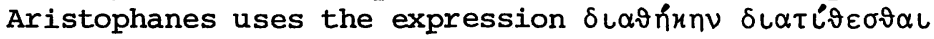
meaning 'to reach an agreement', 'to conclude a treaty' (Birds 440f). ${ }^{21}$ What is described is a treaty between two parties, but binding only upon the one according to the terms fixed by the other. 22 In this context $\delta \iota \alpha \vartheta n$ is properly understood as an arrangement or covenant. The translators of the septuagint, of course, chose $\delta\llcorner\alpha \vartheta \hat{n}$, rather than the cognate $\sigma u \nu \vartheta \eta u n$, to express the unilateral character of the covenant which


2 Corinthians 3:6 points clearly to Jeremiah 31:31 (LXX

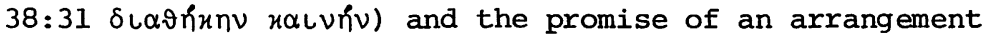
qualitatively different from the older Mosaic covenant. The use of $\delta \iota \alpha \vartheta n$ ń by Aristophanes in the sense of 'treaty' or 'covenant' suggests that others less familiar with the concept of the covenant in the old Testament would nevertheless have understood Paul's intention. There is sufficient linguistic evidence to warrant the conclusion that within the context of 2

19. Epictetus, Diss. 3.22, 26, 28, 69; 4.7, 20, 24, 65 . Cf. Philo, De Gig. 3, 12; De Jos. 40, 241.

20. See $M M$ 148f; W. D. Ferguson, The Legal Terms Common to the Macedonian Inscriptions and the New Testament (Chicago, 1913), $42 \mathrm{ff}$.

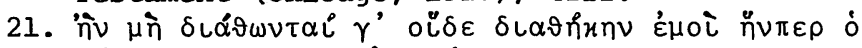

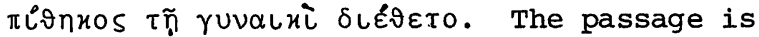
discussed by J. Behm, TDNT 2, 125.

22. See also the discussion of Aristophanes in MM 148. 23. Cf. J. Behm, TDNT 2, 126f. 
Corinthians 3:6 Paul's readers would understand him to be saying that he was 'the messenger of the New Covenant'. In a situation of church discipline, the statement identifies the Apostle as the messenger of the covenant lawsuit God has brought against his rebellious vassals at Corinth.

Paul's appearance and manner, however, offended the Corinthians. They described his bodily presence as 'weak' and his speech as 'ineffective' (2 Cor. 10:10). He did not appear to reflect the splendour which attends the ministry of the New Covenant (cf. 2 Cor. 3:7-11). Throughout the letter it is evident that Paul found it necessary to respond to complaints and charges the Corinthians had lodged against him. He determined to rehearse once more 'the signs of the true apostle' (12:12) which the church had failed to perceive in his ministry. The messenger of the covenant is depicted as scarred from affliction and weakness. His own existence is characterized by death in spite of the fact that the life which flows to others from his ministry authenticates his service for his Lord (4: 10-12). Unable to boast of honour and power, he is like his Lord, a suffering and dying figure who experiences triumph only in the context of infirmity and defeat (2: $14-16 ; 4: 7-12 ; 6: 4-10 ; 11: 23-29 ; 13: 2-4)$. What the Corinthians in their arrogance had failed to detect was the tension between inward glory and outward frailty which distinguishes the apostle as a man laden 'with gifts from his Iord, and with suffering in the world'. ${ }^{24}$ Paul insists that his sufficiency lies in God alone, who qualified him to be the messenger of the New Covenant $(2: 17 ; 3: 6 ; 4: 1 f, 7,16)$.

On the model of the royal messenger of an offended suzerain, Paul's task was the reconciliation of the offending Corinthians to their sovereign God. He affirmed that God had entrusted to him 'the ministry of reconciliation' $(5: 18)$, and he defined the word which he delivered for God as 'the message of reconciliation' (5:19). In his role as messenger of the covenant

24. J. Munck, Paul 186. Cf. E. Güttgemanns, Der leidende Apostel und sein Herr (Göttingen, 1966) 142-170, and the remarks of $\mathrm{K}$. Stendahl on Paul's 'weakness'. Paul 40-52. 
lawsuit, Paul earnestly appealed for reconciliation to God, and to himself:

So we are emissaries for Christ, God making his appeal through us. We beseech you on behalf of Christ, be reconciled to God... Working together with him, then, we entreat you not to accept the grace of God in vain. For he says,

'At the acceptable time I have listened to you, and helped you on the day of vindication.'

Behold, now is the acceptable time; behold, now is the day of vindication (2 Cor. 5:20-6:2).

The point that reconciliation to God demanded reconciliation to his messenger is forcefully made by Paul through the citation of Isaiah 49:8a in 2 Corinthians $6: 2$.

Both the form of the citation and its context deserve attention. The statement is cast in the form of direct address, employing the personal pronoun in the singular: 'At the acceptable time I have listened to you and helped you on the day of vindication!' The context in Isaiah 49 describes the humiliation of the servant of the Lord who was despised by the Gentiles (Is. 49:4,7) . God, nevertheless, assures him that he has listened to his cry, and that the divine intention will be accomplished through him ('I have kept you and given you as a covenant to the people', Is. 49:8b). The presence of the servant among the Gentiles is the pledge that God has graciously extended the blessings of the covenant to them. If the people persist in displaying contempt for God and for his messenger, however, God will vindicate his servant by dealing severely with them. The assurance of vindication accounts for the exultant note on which the passage about the servant ends: 'Sing for joy, o heavens, and exult, 0 earth; break forth, o mountains, into singing! For the Lord has comforted his people, and will have compassion on his afflicted ones' (Is. 49:13).

Paul found in this recital of the call, disparagement, and vindication of the servant in Isaiah 49 a paradigm for his relationship with the Corinthians. He is the servant of the Lord who has been 'deeply despised and 
abhorred' by the Gentiles, whose labours at Corinth appear to have been 'for nothing'. But he warns the Corinthians that the time of God's tolerance of insubordination is past (2 Cor. $6: 2 b$, 'now is the day of vindication'l. Paul will be vindicated as God's servant among the Gentiles because his presence mediates the covenant for the Corinthians in the same measure as the servant of Isaiah 49 was the pledge of the divine covenant with Israel. Failure to recognize this would only expose the Corinthians to the experience of rejection by God. The grace of God can be accepted in vain when the covenant with God is disparaged (2 Cor. 6:1). Paul's earnest appeal for the Corinthians to be reconciled to himself is sustained as he seeks to remove every obstacle which might hinder the achievement of reconciliation $(6: 3-13)$.

Paul's appropriation of Isaiah 49:1-13 to interpret his own role among the Corinthians provided him with the distinctive vocabulary of 'comfort' and 'affliction'. The call in Isaiah 49 for celebration after abject humiliation is based upon the fact that 'the Lord has comforted his people, and will have compassion upon his afflicted ones' (Is. 49:13). Paul experienced the comfort of God when Titus reported that the Corinthians were eager for reconciliation and had acted to rectify the estranged relationship between themselves and the Apostle. 2 Corinthians is the response to that report. In the place ordinarily devoted to the thanksgiving section of the letter Paul substituted the balanced clauses of a benediction which sounds alternately the notes of 'comfort' and 'affliction' (1:3-4), followed by a reflective meditation upon his own experience of comfort and affliction in his relationship with the Corinthians $(1: 5-7)$.

The sonorous, balanced rhythm of the benediction, achieved through the repetition of vocabulary and phrases, must not obscure the fact that Paul's statement refers specifically to 'the affliction' he experienced in Asia:

For we do not want you to be ignorant, brethren, of the affliction we experienced in Asia; for we were so utterly, unbearably crushed that we despaired of life itself. Why, we felt that we had received the verdict of death; but that was to make us rely not on ourselves but on God who raises the dead; he delivered us from so deadly a peril... (1:8-10). 
The reference to 'Asia' is commonly understood to be an allusion to Ephesus, the metropolis of the Roman province of Asia. ${ }^{25}$ When Paul writes further of this experience in Asia, however, he refers to Troas, a Roman colony in the north-western section of the province:

When I came to Troas to preach the gospel of Christ, a door was opened for me in the Lord, but my mind could not rest because I did not find my brother Titus there. So I took leave of them and went on to Macedonia (2 Cor. 2:12-13).

Paul had arranged to meet Titus in Troas, after a period of time deemed sufficient for delivery of the severe letter, determination of the response it elicited, and return overland by way of Macedonia to the Asian mainland. When Titus was delayed, Paul experienced unrelieved anxiety over the outcome of the mission. In retrospect he speaks of an 'unbearable crushing' that reduced him to despair of life itself $(1: 8)$. He anticipated that the Corinthians would reject his appeal, that is, that he had received from them their verdict, and it entailed death (cf. $2: 16 ; 7: 10) .^{26}$ It was this affliction which was relieved when he found Titus and learned of the response to his letter.

When Paul wrote 2 Corinthians he knew that the response was favourable, and his profound relief is expressed in a spontaneous thanksgiving to God who triumphs in every situation (2:14-17). The rush of emotion disrupted his train of thought and redirected it to a consideration of the ministry entrusted to him $(3: 1-7: 1)$. When the Apostle resumed the line of thought he was developing in 2:13-14, however, he returned to the vocabulary of comfort and affliction:

25. This opinion is advanced in the earliest consideration of the passage that has been preserved, Tertullian, De Resurrectione Carnis 48, who links 2 Cor. 1:8-10 with 1 Cor. 15:30-32.

26. On $\alpha \pi \delta \delta_{\rho} \mu \alpha$ as a technical term for an official decision in response to a petition by an embassy, see C. J. Hemer, 'A Note on 2 Corinthians 1:9', TB 23 (1972) 103-107. 
I am filled with comfort. With all our affliction, I am overjoyed.

For even when we came into Macedonia, our bodies had no rest but we were afflicted at every turn - fighting without and fear within. But God, who comforts the downcast, comforted us by the coming of Titus, and not only by his coming but also by the comfort with which he was comforted in you....

Therefore we are comforted. And besides our own comfort we rejoiced still more at the joy of Titus, because his mind has been set at rest by you all.... I rejoice, because I have perfect confidence in you (2 Cor. $7: 4-7,13,16)$.

Paul concludes his solemn review of the course of events from the time he wrote the 'letter of tears' to the moment when he experienced profound relief at Titus's report on the note that he has been comforted.

The emphatic use of the vocabulary of comfort and affliction indicates thoughtful interaction with Isaiah 49:13. In framing the response to the report of Titus by referring to 'the God of all comfort' in the initial benediction $(1: 3)$ and to 'God, who comforts the downcast' $(7: 6)$ in the concluding paragraph, Paul placed the discussion in the context of God's intention and achievement. Paul had functioned as the messenger and pledge of the New Covenant in the establishment and direction of the church. Consequently, the disparagement of the Apostle entailed contempt for God and demanded that the sanctions of the covenant be imposed. In the favourable response of the Corinthians Paul experienced the vindication and comfort promised in Isaiah 49.

The central theological statement of 2 Corinthians is brought to conclusion by $6: 14-7: 1$. This unit has often been regarded as an interpolation in the letter because its subject matter appears to be radically different both from the preceding verses $(6: 1-13)$ and from those that follow $(7: 2-4) \cdot 27$ The style and vocabulary of the

27. See, for example, E. B. Allo, Saint Paul. Seconde Épître aux Corinthiens (Paris, 1956²) 189-193; G. Bornkamm, 'The History of the So-called second Letter to the Corinthians', NTS 8 (1961/62) 
section are commonly regarded as uncharacteristic of Paul or the New Testament. 28 It is beyond the scope of this paper to examine this passage in detail. This has been done effectively by G. D. Fee, who has shown that the function of $6: 14-7: 1$ is to warn the Corinthians that they cannot continue to participate in banquets held in pagan temples. ${ }^{29}$ Continued attendance at such banquets involves an exposure to idolatry and a tacit acknowledgment of other allegiances, both of which are incompatible with fidelity to the sovereign God. The passage develops Paul's instructions in 1 Corinthians 10: 14-22. What makes it relevant to this study is that this disputed passage is thoroughly consistent with the covenant ideology underlying 2 Corinthians 3:1-7:1.

The key to the interpretation of $6: 14-7: 1$ is provided in $7: 1$, where Paul underscores the promise-character of the old Testament texts he cited in 6:16-18:

Since we have these promises, beloved, let us cleanse ourselves from every defilement of body and spirit, and make holiness perfect in the fear of God.

The 'promises' to which Paul alludes refer to the blessings promised by God to those who obey the stipulations of the covenant. At this point Paul carries forward a theme introduced early in the letter in a context which is clearly covenantal in character. Paul assured the Corinthians that 'all the promises of God' find their

258-264; J. C. Hurd, The Origin of 1 Corinthians (London, 1965) 43-47.

28. H. D. Betz, '2 Cor. 6:14-7:1: An Anti-Pauline Fragment?' JBL 92 (1973) 88-108; J. A. Fitzmyer, 'Qumran and the Interpolated Paragraph in 2 Cor. 6: 14-7:1', in Essays on the Semitic Background of the New Testament (Iondon, 1971) 205-217; J. Gnilka, '2 Kor. 6,14-7.,1 im Lichte der Qumranschrift und der Zwölf-Patriarchen-Testamente', in Neutestamentliche Aufsätze (Festschrift für J. Schmid, ed. J. Blinzler et al., Regensburg, 1963) 86-99.

29. G. D. Fee, 'II Corinthians (vi.14-vii.1 and Food offered to Idols', NTS 23 (1976/77) 140-161. 
affirmation in Jesus Christ, and adds, 'That is why we utter the Amen through him to the glory of God' (2 Cor. 1:20). The declaration of 'Amen' is an idiom which comes from the thought-world surrounding the ratification of an international treaty. Both biblical and extrabiblical accounts of solemn covenant ritual attest that the vassal gave an 'Amen' response in such ceremonies. His 'Amen' amounted to an oath of allegiance. ${ }^{30}$ The Corinthian 'Amen' uttered in the name of Christ is essentially a confession of faith in the promises of God expressed in the New Covenant, and an acknowledgment of the sovereign lordship of the God who promises. When in 7:1 Paul appeals to the certainty of the promises of God he intends his statement to be informed by his prior reference to the promises of the New Covenant ratified through Jesus Christ $(1: 20)$ and to the oath of allegiance which the Corinthians have sworn to God.

The biblical texts cited in 6:16-18, which substantiate the affirmation that 'we are the temple of the living God' (6:16), convey the promise of God's presence with his people. The three citations share a firm basis in covenant ideology. They refer to a new covenant in the messianic age or to the renewal of the great covenants of the past, particularly those with Moses and David. They furnish an appropriate conclusion to a major section in 2 Corinthians $(3: 1-7: 1)$ which develops the 'newness' of the New Covenant as reinforcement for Paul's plea for full reconciliation with God.

The recognition of the covenantal frame of reference in 6:14-7:1 sheds light on the character of the exhortations which precede the recital of the promises of the covenant to which the Corinthians are heirs (6:14-16). A common feature of the covenantal pattern was the stipulation that the vassal should not become entangled in foreign relationships. Paul echoes this demand in 6:14f, when he calls for the Corinthians to discontinue the practice of sharing meals with unbelievers in a temple dedicated to an idol (cf. 1 Cor. 8:10; 10:7-22). The series of questions which underscores the prohibition of being 'yoked together with unbelievers' $(6: 14-16)$ is reminiscent of the interrogative form of the indictment in the lawsuit passages in the old Testament. The call for a life of separation to the Lord is based upon the

30. See especially M. Kline, 'Abram's Amen', WTJ 31 (1968) 1-11. 
fact that God has ratified the New Covenant with the Corinthians through Jesus Christ (1:20; 6:15). If the Corinthians are to be reconciled to God they must recognize his rightful claim to their total allegiance.

In 2 Corinthians 6:14-7:1 Paul addresses an unresolved pastoral problem and places the issue in a distinctly covenantal frame of reference. He answers the charge that he is restricting the freedom of the Corinthians by stressing the positive character of the promises God made to his covenant people. Having done so, he may appropriately return to his plea for reconciliation, insisting 'we have wronged no one, we have corrupted no one, we have taken advantage of no one' $(7: 2)$. The confidence that Paul has in the Corinthians $(7: 4,16)$ is that they will recognize their covenant obligations and will be fully restored to God. Recognition of the covenantal framework of the argument in 2 Corinthians 6: 14-7:1 does much to remove the objections which have been marshalled against the authenticity and propriety of this section of Paul's letter. This literary unit significantly advances Paul's discussion of covenant status and obligation and prepares for the resumption of his response to the repentance of the church.

In chapters 8-13 Paul addresses a number of other issues which remained unresolved at corinth. The unit concerning the collection (8:1-9:15) raises the issue of the integrity of the Corinthians. They had initially expressed enthusiasm for participation in a monetary gift to be presented by the Gentile Christians to the Jewish Christians in Jerusalem (8:10-11). But their interest in the project had lapsed, and after a year they had failed to keep their commitment. They had only recently reaffirmed their repentance and obedience, as well as their affection for Paul (7:7, 9-11, 15). Paul proposes the resumption of the collection project as the pledge of their good faith: 'I am not commanding you, but I want to test the sincerity of your love by comparing it with the earnestness of others' (8:18). The completed collection will provide 'the proof of your love' (8:24); it will be 'the service by which you have proved yourselves', an expression of 'the obedience that accompanies your confession of the gospel of Christ' $(9: 13)$. In short, the renewal of their commitment to the collection will provide the Corinthians with an additional opportunity to acknowledge their covenant status and obligation. On Paul's instructions, Titus returned to 
Corinth in the company of two other men to assist the Corinthians to complete their arrangements for the generous gift they had promised $(8: 6,16-23) ; 9: 3-5) .{ }^{31}$

In the final section of the letter, chapters 10-13, Paul addresses those members of the congregation who remained unreconciled to himself and to God. The concern for reconciliation and restoration of the Corinthians to the blessings of the covenant explains the tension between joy and solemn warning that characterizes this unit. At this point, more than elsewhere in the letter, Paul's statement approaches the conventional formulations of the covenant lawsuit. The Apostle introduces the imagery of warfare and weaponry in 10:3-6 in pleading for a softening of the hardened disposition of the recalcitrant at Corinth:

For though we live in the world we are not carrying on a worldly war, for the weapons of our warfare... have divine power to destroy strongholds. We destroy arguments and every proud obstacle to the knowledge of God, and take every thought captive to obey Christ, being ready to punish every disobedience.

Paul's language echoes the threat of an angered suzerain to his faithless vassal: he will overthrow his vassal's towers and lead his people captive; he will destroy his boastful arguments and punish his disobedience. Like the royal messenger of the covenant lawsuit in the ancient Near East, Paul is vested with the authority of the Great King. Drawing upon the distinctive language of Jeremiah, he insists that he wants to exercise that authority for 'building up' and not for 'tearing down' (10:8; cf. 13:10). But Paul is certain that if a contest of wills should ensue, he will not be put to shame. His suzerain will stand behind him and give him the executive power to perform what he has said he will do in the administration of covenant discipline (10:8-11).

The metaphor of the betrothal contract (11:1-2) provides another image for covenant relationship. The imagery was undoubtedly suggested from the prophetic depiction

31. See further K. F. Nickle, The Collection. A Study in Pauline Strategy (London, 1966) with full bibliography. 
of Yahweh as the husband of an unfaithful wife in Hosea, Jeremiah, and Ezekiel (cf. Hos. 2:19). It serves to reinforce the Apostle's plea for covenant loyalty. Paul expresses grave concern that the Corinthians may yet be led away from 'a sincere and pure devotion to Christ' $(11: 31$, and that the tokens of their repentance (cf. $7: 7,11,15$ ) will prove insufficient.

The principal cause for Paul's concern is the Corinthian enthusiasm for certain exploiters of the congregation, whom he labels contemptuously 'the superlative apostles' (11:5; 12:11).32 These men were actually 'false apostles, deceitful workmen, who disguise themselves as apostles of Christ' (11:13). Paul finds it necessary to confront their spurious claim to apostolicity with his own apostolic credentials in order to shame a confused and disloyal congregation (11:5-12:13).

Equally serious was the perpetuation of practices which clearly violated the ethical stipulations of the covenant (12:20-13:10). Paul's solemn warning reiterates the rebuke delivered on the occasion of his second visit:

I fear that perhaps I may come and find you not what I wish, and that you may find me not what you wish; that perhaps there may be quarrelling, jealousy, anger, selfishness, slander, gossip, conceit and disorder. I fear that when I come again my God may humble me before you, and I may have to mourn over many of those who sinned before and have not repented of the impurity, immorality, and licentiousness which they have practised. This is the third time I am

32. On the question of the 'super-apostles' see J. L. Martyn, 'Epistemology at the Turn of the Ages: 2 Corinthians 5:16', in Christian History and Interpretation: Studies Presented to John Knox, ed. W. R. Farmer et al. (Cambridge, 1971) 279-286; R. Schnackenburg, 'Apostles Before and During Paul's Time', in Apostolic History and the Gospel, ed. W. W. Gasque and R. P. Martin (Grand Rapids, 1970) 296-299, 301, and esp. 296, n. 2 for relevant bibliography. 
coming to you. Any charge must be sustained by the evidence of two or three witnesses. I warned those who sinned before and all the others, and I warn them now while absent, as I did when present on my second visit, that if I come again I will not spare them since you desire proof that Christ is speaking in me (12:20-13:31.

The warning is focused upon the transgression of law and its consequences. When Paul comes a lawsuit will ensue, in which every charge must be substantiated by the agreement of witnesses. The Corinthians are asked to examine themselves to determine if they have been faithful in their allegiance to their suzerain, Jesus Christ $(13: 5)$. Failure to demonstrate an acceptable repentance will be severely punished. Paul's letter provides the incentive and the opportunity for the correction of irregularities; he is writing to them 'in order that when I come I may not have to be severe in my use of the authority which the Lord has given me for building up, and not for tearing down' (13:10). His final admonition was the pointed counsel, 'Mend your ways; heed my appeal' (13:11).

The appeal is Paul's because it was delivered through him. But it is the same appeal to which he had referred at an earlier point in the letter when he spoke of 'God making his appeal through us. We beseech you, on behalf of Christ, be reconciled to God' $(5: 20)$. The language of indictment, warning, and ultimatum, in a context which refers to the prospect of a forthcoming trial, conforms to that type of the $R \hat{I} b$ pattern which is climaxed by warning and stern admonition. The recognition of this fact does much to account for the tone and character of chapters 10-13.

In summary, Paul recognized that his function as Apostle to the Gentiles was determined by his appointment to the prophetic office in the service of the New Covenant. In the specific instance of the church at Corinth this meant assuming the role of messenger of the covenant lawsuit. Paul saw the issue at Corinth as disregard for the provisions of the New Covenant ratified through Jesus Christ. Covenant is the key to Paul's conflict with Corinth. The severe letter he dispatched to the congregation with Titus was an ultimatum, corresponding to the first stage in a conventional covenant lawsuit. In fact, the various 
components of the relationship between Paul and the Corinthians correspond to the more significant aspects of the messenger-vassal relationship attested in the international treaties and in the oT prophets.

Iike the prophet Jeremiah, Paul experienced his share of prophetic agony. He insists that he had taken no delight in writing the severe letter which posed the ultimatum to the church; he shrank from the thought that he would have to exercise the power with which he was vested to tear down what he had laboured to build up. But Paul was not a free agent. He was himself the vassal of God, who is exhibited among the captives who add splendour to the divine triumphal procession throughout the world (2:14-17). Paul wrote to the Corinthians in all of his humanity, exposing the depth of his emotional life to full view. He knew that their response to the word he delivered would result in their life or death, for an appeal to the covenant stipulations and sanctions necessitates a decision for God or against him.

Refusing to tamper with the divine word entrusted to him, the Apostle committed himself to the open statement of the truth in the sight of God $(2: 17 ; 4: 2 ; 13: 8)$. The distinguishing marks of his ministry were 'truthful speech and the power of God' $(6: 7)$, those qualities which distinguished the prophets in their role as messengers of the covenant lawsuit. Paul's refusal to compromise the truth, even when its import conflicted with his own human inclinations, reinforced the summons to fidelity to the sovereign God which the Apostle delivered to the church at corinth by emissary and by letter. 